\title{
PENINGKATAN HASIL BELAJAR KEBUGARAN JASMANI MELALUI PENERAPAN MODEL PEMBELAJARAN KOOPERATIF STAD
}

\section{Gusti Putu Yulianingsih}

\author{
SMP Negeri 3 Sawan, Buleleng, Indonesia \\ e-mail: yulianiigp@gmail.com
}

\begin{abstract}
Abstrak
Penelitian ini bertujuan meningkatkan hasil belajar kebugaran jasmani mata pelajaran penjasorkes melalui model pembelajaran Student Teams Achievement Division (STAD). Penelitian tindakan kelas dilaksanakan dua siklus, terdiri dari rencana tindakan, pelaksanaan tindakan, observasi/evaluasi dan refleksi. Subjek penelitian adalah siswa kelas IXA6 SMP Negeri 3 Sawan, berjumlah 32 orang dengan rincian 15 putra dan 17 putri. Data dianalisis menggunakan analisis statistik deskriptif. Analisis data hasil belajar kebugaran jasmani setelah diberi tindakan pada tiap siklus terjadi peningkatan yang sangat signifikan dilihat ketuntasan pada siklus pertama sebesar $71.9 \%$ dan pada siklus ke dua sebesar $90.6 \%$. Berdasarkan hasil analisis data dan pembahasan disimpulkan bahwa hasil belajar kebugaran jasmani mata pelajaran pendidikan jasmani olahraga dan kesehatan pada semester genap Siswa kelas IXA6 SMP Negeri 3 Sawan Tahun pelajaran 2015/2016 meningkat melalui penerapan model pembelajaran kooperatif student teams achievement division (STAD). Disarankan kepada guru penjasorkes menggunakan model pembelajaran kooperatif dalam proses pembelajaran, karena terbukti efektif meningkatkan hasil belajar kebugaran jasmani siswa.
\end{abstract}

Kata kunci: Model Pembelajaran, STAD, Hasil Belajar, Kebugaran Jasmani

\begin{abstract}
This study aims to improve the physical fitness learning outcomes of physical education subjects through the Student Teams Achievement Division (STAD) learning model. Class action research is carried out in two cycles, consisting of action plans, implementation of actions, observation/evaluation and reflection. The research subjects were class IXA6 students of SMP Negeri 3 Sawan, totaling 32 people with details of 15 sons and 17 daughters. Data were analyzed using descriptive statistical analysis. Analysis of physical fitness learning outcomes data after being given action in each cycle occurred a very significant increase seen completeness in the first cycle of $71.9 \%$ and the second cycle of $90.6 \%$. Based on the results of data analysis and discussion it was concluded that the physical fitness learning outcomes of sports and health physical education subjects in the even semester of class IXA6 Sawan Middle School 3 Year 2015/2016 academic year increased through the application of cooperative learning models student teams achievement division (STAD). It recommended that physical education teachers use collaborative learning models in the learning process because it is proven to be effective in improving student tangible fitness learning outcomes..
\end{abstract}

Keywords: Learning Mode, STAD, Learning Outcomes, Physical Fitness 


\section{Pendahuluan}

Pendidikan jasmani, olahraga, dan kesehatan merupakan bagian integral dari pendidikan secara keseluruhan, bertujuan untuk mengembangkan aspek kebugaran jasmani, keterampilan gerak, keterampilan sosial, penalaran, stabilitas emosional, tindakan moral, aspek pola hidup sehat dan pengenalan lingkungan bersih melalui aktivitas jasmani, olahraga dan kesehatan terpilih yang direncanakan secara sistematis dalam rangka mencapai tujuan pendidikan nasional. Dengan demikian, pendidikan jasmani, olahraga, dan kesehatan tidak hanya berpengaruh terhadap pertumbuhan fisik tetapi memberi kontribusi terhadap perkembangan intelektual siswa.

Pendidikan Jasmani mengandung makna pendidikan menggunakan aktivitas jasmani untuk menghasilkan peningkatan secara menyeluruh terhadap kualitas fisik, mental, dan emosional peserta didik. Kata aktivitas jasmani mengandung makna pembelajaran adalah berbasis aktivitas fisik. Kata olahraga mengandung makna aktivitas jasmani yang dilakukan dengan tujuan untuk memelihara kesehatan dan memperkuat otot-otot tubuh. Kegiatan ini dapat dilakukan sebagai kegiatan yang menghibur, menyenangkan atau juga dilakukan dengan tujuan untuk meningkatkan prestasi. Sementara kualitas fisik, mental dan emosional disini bermakna, pembelajaran PJOK membuat peserta didik memiliki kesehatan yang baik, kemampuan fisik, memiliki pemahaman yang benar, memiliki sikap yang baik tentang aktifitas fisik, sehingga sepanjang hidupnya mereka akan memiliki gaya hidup sehat dan aktif.

Mutu pendidikan dapat di tingkatkan jika proses pembelajaran berlangsung secara efektif, bermakna dan ditunjang oleh adanya sumberdaya manusia, sarana dan prasarana, dan dana yang memadai. Ketika semua sarana pendukung sudah terpenuhi maka yang menjadi penenkanan terhadap hasil belajar peserta didik adalah kualitas sumber daya manusia yang dalam hal ini adalah guru sebagai tenaga pendidik yang memberikan sebuah motivasi belajar untuk mencapai target yang di canangkan pada tiap jenjang pendidikannya.

Proses dan metode pembelajaran yang inovatif akan berdampak pada hasil belajar yang lebih maksimal, dimana metode pembelajaran yang memiliki fase-fase secara detail melibatkan banyak orang dengan pengaturan pengelompokan yang hiterogen akan lebih hidup proses pembelajarannya dalam aktivtas pembelajaran pendidikan jasmani. Siswa yang terlibat dalam pembelajaran akan lebih aktif dan menggeluarkan kemampuannya untuk sebuah penampilan belajar yang terbaik dikelompoknya. Namun apa yang diharapkan masih jauh dari yang di targetkan dimana kalau dilihat di setiap standar kompetensi pendidikan jasmani masih dominan pada olahraga permainan. Ketika memasuki materi kebugaran jasmani aktivitas belajar anak sedikit menurun dan cenderung lebih banyak mengeluh tidak ada aktivitas bermain, capek dengan gerakan - gerakan yang dilakukan dan otot - otot yang dilatih terasa berat menimbulkan rasa sakit. Dengan kondisi pembelajaran demikian sudah barang tentu berdampak terhadap hasil belajar siswa.

Hasil belajar merupakan suatu puncak dari proses. Hasil belajar tersebut terjadi berkat evaluasi guru dan juga merupakan hasil dari suatu interaksi tindak belajar dan tindak mengajar. Dari sisi guru, tindak mengajar diakhiri proses evaluasi hasil belajar. Sedangkan dari siswa, hasil belajar merupakan puncak proses belajar (Dimyati dan Mudjiono, 2006: 3). Menurut taksonomi instruksional Bloom dan kawan-kawan (dalam Dimyati dan Mudjiono, 2006: 26) mengkategorikan jenis perilaku dan kemampuan internal akibat belajar antara lain: a) Ranah kognitif, b) Ranah Afektif, c) Ranah Psikomotor. Ranah yang menjadi skala prioritas dan pilihan yang paling dominan di dalam melakukan aktivitas jasmani, olahraga dan kesehatan adalah ranah psikomotor, sebab ranah ini merupakan ranah yang menitik beratkan pada aspek keterampilan gerak.

Seseorang yang memiliki kesegaran jasmani yang baik akan terhindar dari kemungkinan cedera yang biasanya sering terjadi saat melakukan kerja fisik yang berat. Kurangnya daya tahan tubuh, kelentukan persendian, kekuatan otot, kecepatan dan kelincahan merupakan penyebab utama timbulnya cedera olahraga. Tujuan utama dari latihan fisik adalah untuk meningkatkan kesegaran jasmani dan kemampuan fungsi 
ergosistem tubuh. Kebugaran jasmani oleh Mahardika (2010:87) adalah bagaimana kemampuan jasmani seseorang dalam melakukan tugas kejasmanian sehari-hari secara optimal bahkan masih dapat melakukan kegiatan jasmani tambahan lainnya tanpa menimbulkan kelelahan yang berarti.

Kebugaran jasmani merupakan sari utama cikal bakal dari kesegaran jasmani secara umum. Jadi apabila orang dalam keadaan segar salah satu aspek pokok yang nampak adalah keadaan penampilan jasmainya. Dengan demikian seseorang tidak dapat mencapai kesegaran jasmani secara menyeluruh atau umum tanpa disadari oleh keadaan kesegaran jasmani yang baik. Kebugaran jasmani dapat diklasifikasikan menjadi dua, yaitu kebugaran jasmani yang berhubungan dengan kesehatan dan kebugaran jasmani yang berhubungan dengan keterampilan gerak.

Setiap standar kompetensi pendidikan jasmani masih dominan pada olahraga permainan. Ketika memasuki materi kebugaran jasmani aktivitas belajar anak sedikit menurun dan cenderung lebih banyak mengeluh tidak ada aktivitas bermain, capek dengan gerakan - gerakan yang dilakukan dan otot - otot yang dilatih terasa berat menimbulkan rasa sakit. Dengan kondisi pembelajaran demikian sudah barang tentu berdampak terhadap hasil belajar siswa. Sesuai dengan masalah di atas maka peneliti mencoba memberikan alternatif pemecahan masalah dengan penerapan model pembelajaran STAD yang mana merupakan salah satu tipe pembelajaran kooperatif yang paling sederhana.

Model pembelajaran kooperatif adalah model pembelajaran dengan cara berkelompok untuk bekerjasama saling membantu mengkonstruksi konsep, menyelesaikan persoalan, dan inkuiri. Slavin (dalam Isjoni, 2007: 15) menyatakan bahwa model pembelajaran kooperatif adalah suatu model pembelajaran yang sistem belajar dan bekerjanya dalam kelompok-kelompok kecil yang berjumlah 4-6 orang secara kolaboratif sehingga dapat merangsang siswa lebih bergairah dalam belajar.

Apabila diperhatikan secara seksama, maka pembelajaran kooperatif ini mempunyai ciri-ciri tertentu dibandingkan dengan model lainnya. Arends (dalam Trianto, 2007: 47) menyatakan bahwa pembelajaran yang menggunakan model pembelajaran kooperatif memiliki ciri-ciri sebagai berikut: (1) siswa bekerja dalam kelompok secara kooperatif untuk menuntaskan materi belajar, (2) kelompok dibentuk dari siswa yang mempunyai kemampuan tinggi, sedang, dan rendah, (3) bila memungkinkan, anggota kelompok dari beda ras, budaya, suku, jenis kelamin yang beragam dan (4) penghargaan lebih berorientasi kepada kelompok dari pada individu.

Model pembelajaran STAD merupakan tipe pembelajaran yang paling sederhana yang mengelompokan siswa menjadi 4-5 siswa secara heterogen. Langkah-langkah pembelajaran STAD adalah diawali dengan menyampaikan tujuan pembelajaran, penyampaian materi, kegiatan kelompok, kuis, dan penghargaan kelompok (Trianto, 2007:52). Menurut Laa (2017) metode kooperatif merupakan metode pembelajaran yang dapat meningkatkan kinerja siswa dalam tugastugas akademik, dan membantu siswa dalam mencapai tujuan pembelajaran. Model STAD menekankan pada aktivitas dan interaksi antara siswa untuk saling membantu dalam menguasai materi pelajaran, guna mencapai tujuan yang diharapkan, siswa di tempatkan dalam tim belajar agar bekerja sama dalam kelompok untuk menyelesaikan tugas yang diberikan oleh guru. Menurut Juraini (2016) Pembelajaran kooperatif tipe STAD ini merupakan salah satu tipe dari model pembelajaran kooperatif dengan menggunakan kelompokkelompok kecil dengan jumlah anggota tiap kelompok 4-5 orang siswa secara heterogen. Diawali dengan penyampaian tujuan pembelajaran, penyampaian materi, kegiatan kelompok, kuis, dan penghargaan kelompok. Menurut Nikmah (2016) STAD adalah salah satu dari tipe pembelajaran kooperatif yang menekankan adanya kerjasama siswa secara berkelompok dalam memecahkan suatu masalah untuk mencapai tujuan belajar. Pembelajaran dengan model STAD mampu menciptakan pembelajaran yang aktif, inovatif, kreatif, dan menyenangkan bagi siswa selama proses pembelajaran. Pembelajaran yang demikian akan mampu membangkitkan semangat bagi siswa untuk belajar sehingga akan berpengaruh terhadap pencapaian hasil belajar siswa yang optimal. 
Meskipun tergolong sederhana namun model pembelajaran ini dapat memberikan kesempatan kepada siswa agar dapat terlibat secara aktif dalam proses belajar gerak dalam kegiatan-kegiatan belajar dan diharapkan dari aktivitas belajar tersebut mampu memberikan dampak yang signifikan terhadap hasil belajar peserta didik.

Pembelajaran kooperatif tipe STAD ini menekankan pada ciri pembelajaran langsung dan merupakan pembelajaran yang sangat mudah untuk diterapkan dalam pembelajaran. Pembelajaran ini didasarkan pada prinsip bahwa siswa bekerja bersama-sama dalam belajar dan bertanggung jawab terhadap belajar teman-temannya dalam tim dan juga dirinya sendiri.

Dalam pembelajaran kooperatif metode STAD, kelompok yang terdiri atas 4 sampai 5 siswa harus mewakili keseimbangan kelas dalam kemampuan akademik, jenis kelamin, dan ras. Peringkat para siswa dalam kemampuan akademik sebaiknya dibuat terlebih dahulu. Masing-masing kelompok terdiri atas siswa dari kelompok atas, seorang dari kelompok bawah dan dua orang siswa dengan kemampuan rata-rata. Hal ini bertujuan agar diperoleh kesetaraan pada masing-masing kelompok tersebut.

Sukidin, dkk. (2002:161) mengemukakan beberapa kelebihan pembelajaran kooperatif tipe STAD, yaitu sebagai berikut. Pertama, siswa lebih mampu mendengarkan, menerima dan menghormati serta menerima orang lain. Kedua, siswa mampu mengidentifikasi akan perasaannya juga perasaan orang lain. Ketiga, siswa dapat menerima pengalaman dan dimengerti orang lain. Keempat, siswa mampu meyakinkan dirinya untuk orang lain dengan membantu orang lain dan menyakinkan dirinya untuk saling memahami dan mengerti. Kelima, siswa mampu mengembangkan potensi individu yang berhasil guna dan berdaya guna, kreatif, bertanggung jawab, mampu mengaktualisasikan dan mengoptimalkan dirinya terhadap perubahan yang terjadi.

Untuk mengetahui hasil kebugaran jasmani siswa diperlukan proses pengukuran yang objektif dalam menghasilkan sebuah data yang lebih akurat. Dalam penelitian alat ukur dan pemberian tindakan yang tepat akan bermanfaat bagi siswa dalam aktivitas kesehariannya dan bermakna bagi hasil belajar pendidikan jasmani olahraga dan kesehatan. Berdasarkan uraian di atas, dipandang penting untuk meneliti Penerapan Model Pembelajaran Kooperatif Student Teams Achievement Division (STAD) untuk Meningkatkan Hasil Belajar Kebugaran Jasmani mata pelajaran pendidikan jasmani olahraga dan kesehatan Pada Semester Genap Siswa Kelas IXA6 SMP Negeri 3 Sawan Tahun Pelajaran 2015/2016.

\section{Metode}

Masalah yang telah dirumuskan di depan dipecahkan melalui penelitian tindakan kelas, yaitu dengan jalan menerapkan model pembelajaran STAD pada siswa kelas IX A6 SMP Negeri 3 Sawan semester genap Tahun Pelajaran 2015/2016. Penelitian tindakan kelas ini akan dilaksanakan dalam 2 siklus, masing- masing siklus terdiri dari 3 kali pertemuan. Masing - masing pertemuaan satu dua dan tiga pemberian materi pada pertemuan ke empat dilakukan penilaian hasil belajar siswa, sedangkan siklus kedua dengan pemberian materi yang bersifat perbaikan aktivitas belajar dari hasil observasi pada siklus I. Masing-masing siklus terdiri dari empat tahapan, yaitu: (a) Rencana tindakan, (b) Pelaksanaan tindakan, (c) Observasi/evaluasi, dan (d) Refleksi dengan penjelasan sebagai berikut.

1) Rencana tindakan

Rencana tindakan menggambarkan secara rinci tentang penyiapan perangkat pembelajaran berupa rencana pembelajaran (skenario pembelajaran), media, bahan dan alat, instrumen pengumpulan data dan analisis data.

2) Pelaksanaan Tindakan

Pada tahap pelaksanaan tindakan menerapkan proses pembelajaran sesuai dengan rencana proses pembelajaran yang telah disusun berdasarkan metode yang digunakan yaitu metode kooeratif STAD. 
3) Observasi/Evaluasi

Observasi dalam penelitian tindakan kelas ini dilakukan dengan tes unjuk kerja (praktik) keterampilan kebugaran jasmani sesuai dengan materi yang telah di pelajari pada pertemuan sebelumnya.

4) Refleksi

Refleksi dilakukan berdasarkan hasil obserasi pada siklus pertama, untuk dimana berdasarkan analisis yang dilakukan ternyata masih ada beberapa siswa yang masih berada pada kategori dibawah rata-rata untuk hasil tes kebugaran jasmaninya dan dalam proses pembelajaran belum menunjukkan motivasi tinggi dalam melakukan setiap tugas gerak yang diberikan.

Teknik pengumpulan data dalam penelitian ini adalah tes unjuk kerja (praktik) tentang, kekuatan otot tangan, daya ledak otot, daya tahan cardiovascular, dan kelentukan. a) Untuk data kekuatan otot tangan dilakukan tes berupa gerakan push up 60 detik, b) pengambilan data daya ledak otot digunakan tes vertical jump, c) untuk data daya tahan cardiovaskuler dilakukan tes lari $2.4 \mathrm{~km}$ lintas alam, d) dan untuk tes kelentukan dilakukan tes kelentukan.

Data yang dihasilkan dalam penelitian ini adalah data berupa hasil tes kekuatan dengan gerakan push up 60 detik, daya ledak otot siswa berupa tes vertical jump, daya tahan berupa tes lari jarak jauh lintas alam berupa waktu tempuh, dan data berupa hasil kelentukan siswa yang memiliki satuan centimeter.

Karena data yang dimiliki terdapat satuan yang berbeda seperti: detik dan centi meter, maka dengan karakteristik data tersebut guru penjasorkes tidak akan dapat dengan mudah memberikan skor kepada setiap murid. Dalam Sriundy Mahardika disebutkan standar skor yang dianjurkan untuk digunakan dalam mata pelajaran penjasorkes adalah T-skor. Argumentasi logis yang dapat dikemukakan berkaitan dengan pilihan ini adalah jenis data sasaran belajar Penjasorkes sangat bervariasi satuannya. Rumus T-score (dalam Mahardika, 2010) yang dimaksud adalah sebagai berikut.

$$
\text { Tskor }=50 \pm 10 \frac{X-\bar{X}}{S D}
$$

Setelah didapatkan t-score dari hasil belajar kebugaran jasmani siswa dilanjutkan dengan distribusi frekuensi berdasarkan data t-score yang diperoleh untuk mengetahui kelas interval, nilai tengah, dan persentase frekuensi kumulatifnya. Rumus yang digunakan dalam menghitung distribusi frekuensi data kebugaran jasmani siswa digunakan rumus Sturges (dalam Koyan, 2007:8).

\section{Rumus Sturges: $k=1+3.3 \log n$}

Untuk mendapatkan sekor kecakapan motorik dasar setiap peserta didik, maka perlu melakukan langkah-langkah perhitunngan sebagai berikut: 1) menghitung rerata standar sekor yang didapat masing-masing peserta didik, 2) menghitung sekor tertinggi (maksimal) yang dicapai oleh peserta didik dan, 3) mengubah rerata menjadi sekor dengan rentangan 14 (dalam Muhamad, 2014), dengan cara:

$$
\text { Nilai peserta didik }=\frac{\text { Skor yang diperoleh peserta didik }}{\text { Skor Maksimal }} \times 100
$$

Data hasil belajar kebugaran jasmani (berupa skor) siswa dicatat dalam lembar penilaian, selanjutnya dianalisis secara deskriptif. Hasil ini di interpretaikan dan disimpulkan digunakan untuk menjawab permasalahan yang dirumuskan. 
1) Rata-rata Kelas

Untuk menghitung rata-rata kelas pada masing-masing siklus digunakan rumus sebagai berikut :

$$
\underline{x}=\frac{\sum x}{N}
$$

Keteragan :

$\underline{x}=$ rata-rata kelas

$\sum x=$ Jumlah seluruh skor

$N$ = Banyaknya subjek

(Suaidin, 2010: 44)

2) Daya Serap

Keberhasilan daya serap siswa dihitung menggunakan rumus sebagai beriktu:

$$
D S=\frac{\bar{X}}{M} X 100 \%
$$

$$
\begin{aligned}
& \text { Keterangan : } \\
& \bar{X}=\text { rata-rata } \\
& M=\text { nilai maksimal } \\
& D S=\text { daya serap }
\end{aligned}
$$

(Suaidin, 2010: 44)

3) Ketuntasan Belajar Kelasikal

Nialai ketuntasan belajar klasikal di tentukan dengan rumus sebagai berikut :

$$
K K=\frac{\text { banyaknya siswa yang telah mencapai } K K M}{N} X 100 \%
$$

Keterangan :

$\mathrm{KK}=$ ketuntasan klasikal

$\mathrm{N}$ = banyaknya siswa

(Suaidin, 2010: 44)

Adapun indikator keberhasilan dalam penelitian ini adalah nilai rata-rata hasil belajar kebugaran jasmani yang disesuaikan dengan Ketuntasan Kriteria Minimal Indikator 76.

\section{Hasil dan Pembahasan}

Penelitian tindakan ini dilakukan pada subjek penelitian terdiri dari 32 orang siswa dengan rincian 15 orang putra dan 17 orang putri kelas IXA6 SMP Negeri 3 Sawan pada semester genap tahun pelajaran 2015/2016. Jika dilihat dari aktivitas belajar siswa dibandingkan dengan aktivtas kompetensi olahraga permainan maka dapat dikatakan dalam kategori motivasi belajar gerak rendah. Ketika memasuki materi kebugaran jasmani aktivitas belajar anak sedikit menurun dan cenderung lebih banyak mengeluh tidak ada aktivitas bermain, capek dengan gerakan - gerakan yang dilakukan dan otot - otot yang dilatih terasa berat menimbulkan rasa sakit. Dengan kondisi pembelajaran demikian sudah barang tentu berdampak terhadap hasil belajar siswa.

Data yang dideskripsikan adalah data tentang hasil pengukuran tingkat kebugaran jasmani siswa dengan menggunakan model pembelajaran kooperatif STAD di kelas IXA6 SMP Negeri 3 Sawan. Data yang ditampilkan meliputi bagaimana proses pelaksanaan setiap 
siklus yang dirancang dengan beberapa kali tindakan (pertemuan) setiap satu siklus sebagaimana yang telah dirancang. Tindakan yang dilakukan dimulai dari proses analisis, refleksi,dan evaluasi kondisi sebelumnya. Berdasarkan hasil evaluasi yang dilakukan pada siklus I (pertama) didapatkan data kebugaran jasmani siswa berdasarkan klasifikasi sebagai berikut.

\section{A. Siklus I}

Pada Siklus pertama dalam penelitian tindakan kelas ini mencangkup beberapa langkah sebagai berikut.

\section{1) Perencanaan}

Penelitian tindakan kelas ini menggunakan perencanaan pembelajaran dengan menerapkan model pembelajaran kooperatif tife STAD. Kegiatan penelitian dirancang dengan didukung oleh sarana, alat dan instrument penelitian berupa lapangan yang datar,lintasan lari, kerucut (cone), papan vertical jump, stopwatch, lepri, silabus,RPP, pedoman evaluasi.

\section{2) Pelaksanaan tindakan}

Kegiatan proses pembelajaran berlangsung dalam tiga kali pertemuan dengan dua kali pertemuan memperaktikkan berbagai bentuk latihan gerakan kebugaran jasmani dan pertemuan ke tiga dilakukan evaluasi hasil belajar. Petemuan pertama dalam proses pembelajaran pada siklus pertama diawalai dengan berbaris dilanjtukan dengan berdoa dan dilakukan absensi siswa. Seperti biasa proses pembelajaran pendidikan jasmani olahraga dan kesehatan selalu di awali dengan gerakan pemanasan dengan durasi waktu kurang lebih 10 menit untuk mempersiapkan kondisi fisik ke proses pembelajaran inti. Untuk gerakan pemanasan dilakukan dengan gerakan statis dan dinamis dilanjtukan dengan lari keluar sekolah. Gerakan pemanasan sudah selesai dilakukan siswa kembali berbaris membuat barisan empat bersap dengan komando dari ketua kelas. Dalam posisi berbaris dijelaskan proses pembelajaran yang akan dilakukan yaitu latihan kekuatan otot lengan, latihan kekuatan otot kaki, latihan daya tahan cardiovaskuler, dan latihan kelentukan. a) Untuk latihan otot lengan dilakukan dengan bentuk gerakan push-up,b) latihan kekuatan otot kaki dilakukan dengan gerakan naik turun tangga, c) latihan daya tahan cardiovaskuler dilakukan dengan cara lari lintas alam, d) latihan kelentukan dilakukan dengan cara cium lutut, gerakan saling menarik berpasangan dll. Pada pertemuan kedua siswa melakukan bentuk gerak yang benar sesuai dengan gerakan yang dilatih. Pembagian kelompok untuk memberikan bentuk gerak dalam memotivasi masing-masing kelompok melakukan aktivitas latihan gerak yang lebih maksimal dengan menekankan pola gerak yang benar supaya apa yang dilakukan berdampak baik bagi sekelompok otot yang dilatih. Pertemuan ketiga mengulangi gerakan-gerakan yang sebelumnya dilatih dan menambah pengulangan gerak untuk meningkatkan keterampilan gerak yang dikuasai sekaligus memberikan beban dengan cara memberikan pola latihan sirkuit traning. Dimana gerak yang sebelumnya yang telah dipelajari dibuat dalam bentuk sirkuit, dengan kurun waktu yang telah ditentukan siswa melakukan pola gerak dimasingmasing post dilanjutkan ke post berikutnya sampai dengan kesemua post sudah dilewati.

3) Observasi Penelitian

Untuk pengambilan data kekuatan otot lengan dilakukan dengan cara melakukan gerakan sit-up selama 60 detik, pengambilan data daya ledak dilakukan dengan cara melakukan tes vertical jump, pengambilan data daya tahan cardiovascular dilakukan dengan lari 2.4 $\mathrm{km}$ di sekitar lingkungan sekolah, dan data kelentukan dilakukan dengan tes kelentukan. Tes ini diberikan kepada siswa pada pertemuan keempat siklus I. Untuk data yang dihasilkan memiliki satuan yang beragam yaitu satuan centimer, waktu tempuh dan pengulangan gerakan maka data tersebut terlebih dahulu dilakukan validasi data menjadi sekor standar dengan uji t-score. Pada siklus I keberhasilan hasil belajar kebugaran 
jasmani siswa masih belum optimal, hal ini tampak pada hasil dari skor yang diperoleh pada tiap tes yang dilakukan. Hasil tes yang didapat sangat berpengaruh terhadap proses pengulangan gerakan yang dilakukan dimana kemampuan melakukan gerak dengan pola gerak yang benar akan berdampak pada hasil tes yang dilakukan. Pada pertemuan pertama dan pertemuan kedua pada siklus pertama masih perlu diberikan pemahaman dan pengulangan gerak yang lebih sehingga mampu menghasilkan hasil belajar yang lebih maksimal.

4) Refleksi

(1) Ketercapaian indikator keberhasilan

Keberhasilan proses penelitian dapat dilihat dari segi ketercapaian hasil belajar secara kelasikal dengan indicator ketercapaian hasil belajar sesuai dengan yang telah ditargetkan yaitu nilai criteria ketuntasan minimal yaitu 76. Dari hasil evaluasi yang telah dilakukan pada siklus pertama didapatkan sejumlah 9 orang tidak memenuhi criteria ketuntasan belajar atau jika dicari tingkat ketuntasan belajar klasikalnya maka didapat sekitar $71.9 \%$ siswa yang kategori tuntas dan sisanya sekitar $28.1 \%$ siswa pada kategori tidak tuntas.

(2) Keunggulan-keunggulan

Keunggulan dalam proses pembelajaran siswa lebih termotivasi dalam pembelajaran di kelompok sesuai proses tagihan gerak pada sirkuit traning yang dirancang.

(3) Kelemahan-kelemahan

Terdapat beberapa siswa tidak serius melakukan aktivitas gerak, dilihat dari pergeseran dari post pertama lanjut ke post berikut bersama kelompoknya.

B. Siklus II

1) Perencanaan

Perencanaan pembelajaran sesuai hasil observasi pada siklus pertama dengan menerapkan model pembelajaran kooperatif tife STAD. Kegiatan pembelajaran dirancang dengan menekankan pada pengulangan gerakan sesuai dengan teknik yang benar serta menambah set dalam latihan gerak yang mengalami hasil belajar yang kurang maksimal. Kegiatan dalam kelompok diberikan pengulangan setiap bentuk gerak yang menjadi point dasar keberhasilan. Kemudian dilanjutkan dengan pola sirkuit traning untuk meningkatkan motivasi belajar dengan pembebanan tambahan set dan repetisi di masing - masing post.

2) Pelaksanaan tindakan

Petemuan pertama dalam proses pembelajaran pada siklus II diawalai dengan berbaris dilanjtukan dengan berdoa dan dilakukan absensi siswa. Pembelajaran di awali dengan gerakan pemanasan dengan durasi waktu kurang lebih 10 menit. Dalam posisi berbaris dijelaskan proses pembelajaran yang akan dilakukan yaitu pengulangan gerakan yang sebelumnya dilakukan dengan menambah set dan refetisi dari kegiatan sebelumnya. Kegiatan pengulangan gerak dilakukan pada tiap kelompoknya dengan rincian gerak; a) Untuk latihan otot lengan dilakukan dengan bentuk gerakan push-up dimana gerakan push-up diberikan secara bergantian antara putra dan putri untuk memberikan kesempatan bagi siswa untuk istirahat setelah melakukan latihan kurang lebih satu menit selanjutnya dilakukan pengulangan ke set berikutnya, b) untuk latihan kekuatan otot kaki dilakukan dengan gerakan naik turun tangga pada tangga yang berjumlah lima tangga dilakukan selama satu menit, c) untuk latihan daya tahan cardiovaskuler dilakukan diawal pembelajaran setelah gerakan pemanasan lari keliling di lintasan sekitar lingkungan sekolah, d) latihan kelentukan dilakukan dengan mengulangi gerakan dan varaiasi latihan yang berbeda dengan tujuan yang sama. Pertemuan kedua langsung menggunakan pola sirkuit traning, dimana aktivitas di masing - masing post diberikan set dan repetisi yang trus meningkat di imbangi dengan istirahat yang cukup. Ketika kelompok yang sedang 
istirahat maka kelompok berikutnya siap untuk mengganti dan lanjut ke post pertama. Pertemuan ketiga bentuk latihan tiap post digeser tidak sama dengan pola sebelumnya. Bentuk latihan pada post pertama dilakukan dengan lebih menekankan ketepatan gerak dengan durasi pengulangan menggunakan waktu. Ketika waktu yang telah ditentukan selesai maka gerakan yang dilakukan dipost tersebut dihentikan dilakukan istirahat sambil menuju ke post berikutnya.

3) Observasi Penelitian

Dalam proses penilaian tampak siswa memiliki motivasi yang tinggi dan menunjukkan bahwa tes yang dilakukan harus dilalui dan harus diselesaikan. Penyelesaian gerak yang dilakukan adalah yang utama dalam pengukuran hasil belajar siswa. Pada siklus II keberhasilan hasil belajar kebugaran jasmani siswa rata-rata meningkat namun belum mampu mencapai seratus pesen, hal ini tampak pada hasil dari tes yang diperoleh. Dalam kondisi yang ideal setiap siswa wajib mencapai indicator keberhasilan yang telah ditentukan, namun apa yang telah kita targetkan sudah barang tentu terdapat hal yang mungkin diluar rencana.

4) Refleksi

(1) Ketercapaian indikator

Dari hasil evaluasi pada siklus ke dua maka didapatkan hasil belajar kebugaran jasmani siswa dengan criteria ketuntasan minimal sebesar 76 yaitu dilihat dari tingkat ketuntasan belajar secara klasikal maka terdapat $90.6 \%$ siswa pada kategori tuntas, dan $9.4 \%$ siswa belum mencapai ketuntasan belajar sesuai dengan yang telah ditargetkan. Akan tetapi dalam penelitian ini sudah dikatakn berhasil meskipun tiga orang diantara mereka tidak tuntas dengan alas an bahwa siwa tersebut dalam kondisi rehabilitasi patah tulang dan ada juga dalam kondisi sakit tidak mampu mengikuti aktivitas olahraga.

(2) Keunggulan-keunggulan

Keunggulan dalam pembelajaran dengan menggunakan STAD dimana siswa memiliki rasa percaya diri didalam kelompoknya untuk menampilkan gerakan sesuai dengan tagihan gerak pada masing-masing post.

(3) Kelemahan-kelemahan

Kelemahan siswa dalam beraktivitas yang lebih maksimal dalam sirkuit traning adalah siswa lebih cepat lelah, memerlukan waktu isitirahat yang cukup untuk melanjutkan ke tugas gerak selanjutnya.

Tujuan dalam penelitian adalah mampu meningkatkan hasil belajar peserta didik dengan menggunakan baik metode, pedekatan maupun teknik dan strategi oleh masingmasing peneliti. Berdasarkan hasil observasi dan analisis pada siklus pertama dan kedua didapatkan hasil belajar kebugaran jasmani yang menjadi sebuah prestasi belajar siswa. Pembelajaran yang menerapakan model pembelajaran cooperative tipe STAD mampu memberikan dan meningkatkan hasil belajar dengan lebih maksimal.

Untuk membandingkan hasil belajar kebugaran jasmani berdasarkan evaluasi siklus I dan siklus II berikut ini di uraikan perbandingan data yang diperoleh dengan pengolahan data yang digunakan. Uraian data yang tertera diatas hanya terbatas pada hasil kebugaran jasmani yang pengukurannya berdasarkan hasil bukan pada pengukuran berdasarkan proses. Artinya hasil belajar kebugaran jasmani siswa dapat dilakukan dari berbagai teknik penilaian dan faktor lain yang menjadi keberhasilan suatu proses pembelajaran bagi siswa. Dengan kajian yang dilakukan peneliti dalam penelitian kebugaran jasmani terkait hasil belajar masih dalam kategori terapan, dimana sebuah proses penelitian dalam aktivitas gerak seharusnya dilakukan treatment yang berlebih dalam pemberian beban gerak supaya berdampak positif bagi peningkatan kapasitas kebugaran jasmani seperti terlihat pada Tabel 1. 
Tabel 1. Rekapitulasi Perbandingan Hasil Belajar Data Siklus I dan Siklus II

\begin{tabular}{clcc}
\hline \multirow{2}{*}{ No. Data } & \multicolumn{2}{c}{ Perbandingan Nilai } \\
\cline { 3 - 4 } & & Siklus I & Siklus II \\
\hline 1 & Jumlah & 2525 & 2433 \\
2 & Jumlah Siswa Tidak Tuntas & 9 & 3 \\
3 & Jumlah Siswa Tuntas & 23 & 29 \\
4 & Prensentasi Ketuntasan Klasikal \% & 71.9 & 90.6 \\
5 & Rata-rata (mean) & 79 & 76 \\
6 & Skor Tertinggi (Max) & 100 & 100 \\
7 & Skor Terendah (Min) & 53 & 61 \\
\hline
\end{tabular}

Berdasarkan temuan-temuan dalam aktivitas kegiatan saat tindakan dalam proses pembelajaran di lapangan, hasil belajar siswa tidak hanya di lihat dari angka dan data semata, namun proses dan makna yang terkandung dari proses ilmiah dalam pembelajaran dan evaluasi yang dilakukan yang harus menjadi tujuan terpenting bagi seorang guru pendidikan jasmani yang lebih professional.

Proses pembelajaran siswa lebih termotivasi dalam pembelajaran di kelompok sesuai proses tagihan gerak pada sirkuit traning yang dirancang. Sesuai dengan penelitian yang telah dilakukan oleh I Komang Bagiasa, bahwa dengan menggunakan pola sirkuit traning siswa lebih termotivasi melakukan aktivitas gerak dimana pola gerak yang dilakukan sebelumnya kemudian dirangkai menjadi beberapa gerakan menjadi sebuah pola sikuit traning. Pola ini sangat memberikan dampak yang positif bagi motivasi belajar gerak siswa karena dalam sirkuit terdapat persaingan antar kelompok untuk tampil yang terbaik dan bersaing sambil bermain dalam lingkup sirkuit. Siswa memiliki rasa percaya diri didalam kelompoknya untuk menampilkan gerakan sesuai dengan tagihan gerak pada masingmasing post.

Dalam kondisi bermain dan rasa bercaya diri setiap siswa mulai tumbuh, perasaan jenuh dan keluhan yang berlebihan mulai redup. Ternyata apa yang telah dirancang dan dan dikerjakan sudah membuahkan hasil yang maksimal mesikipun tergolong sederhana namun bagi seorang peneliti merupakan prestasi yang luar biasa.

Dengan pemberian tindakan dalam proses penelitian terdapat keunggulan-keunggulan hasil tindakan yang diberikan diantaranya setiap siswa memiliki kesempatan untuk memberikan kontribusi dalam bentuk gerak di setiap tagihan gerak bersama kelompoknya, interaksi siswa lebih aktif dan kerjasama antar kelompoknya menjadi lebih baik, melatih siswa dalam pengembangan aspek kecakapan social disamping kecakapan motorik, kompetisi pembelajaran yang terjadi menjadi lebih hidup, prestasi hasil belajar bisa didapatkan oleh semua kelompok.

\section{Simpulan dan Saran}

Pembelajaran yang digunakan dalam penelitian ini sudah menjawab permasalahan peneliti dalam proses dan hasil belajar yang lebih maksimal. Hasil belajar kebugaran jasmani siswa pada siklus pertama dan siklus kedua terjadi peningkatan yang sangat signifikan dilihat dari ketuntasan pada siklus pertama sebesar $71.9 \%$ dan pada siklus ke dua sebesar $90.6 \%$. residu ketuntasan klasikal yang diperoleh yaitu sebesar $18.8 \%$. Jadi dari peningkatan tersebut dapat ditarik kesemipulan bahwa Penerapan Model Pembelajaran Kooperatif Student Teams Achievement Division (STAD) Terhadap Hasil Belajar Kebugaran Jasmani Penjasorkes Semester Genap Siswa Kelas IXA6 SMP Negeri 3 Sawan meningkat.

Berdasarkan atas simpulan yang telah dibahas diatas, peneliti memberikan beberapa saran dan rekomendasi bagi tenaga kependidikan khususnya guru pendidikan jasmani sebagai berikut. Pertama, model pembelajaran yang tepat akan berdampak besar bagi 
keberhasilan sebuah proses pembelajaran, khusus bagi guru penjasorkes salah satu upaya untuk meningkatkan hasil belajar siswa pada kompetensi kebugaran jasmani disarankan menggunakan model pembelajaran kooperatif tipe STAD untuk hasil belajar yang lebih oftimal. Kedua, bagi peneliti lain yang melakukan penelitian hendaknya mencoba melakukan penelitian yang sejenis sehingga dapat mengetahui kelemahan dan kelebihan dari pendekatan pembelajaran. Terakhir, bagi sekolah, hendaknya lebih banyak memberikan kesempatan bagi tenaga pendidik dalam mengembangkan diri pada bidang penelitian khususnya pada penelitian tindakan dan mempasilitasi semua kebutuhan proses pembelajaran.

\section{Daftar Rujukan}

Dimyati dan Mudjiono. 2006. Belajar dan Pembelajaran. Jakarta: Rineka Cipta.

Djamarah dan Zain 2002. Strategi Belajar Mengajar. Jakarta: Rineka Cipta.

Hamalik, Oemar. 2004. Proses Belajar Mengajar. Jakarta: Bumi Aksara.

Haryati, Mimin. 2007. Model dan Teknik Penilaian Pada Tingkat Satuan Pendidikan. Jakarta: Gaung Persada Press.

Isjoni . 2007. Pembelajaran Kooperatif. Yogyakarta. Pustaka Pelajar.

Juraini, Muhammad Taufik, I Wayan Gunada. 2016. Pengaruh Model Pembelajaran Kooperatif Tipe STAD (Student Team Achievement Division) dengan Metode Eksperimen terhadap Keterampilan Proses Sains dan Hasil Belajar Fisika pada Siswa SMA Negeri 1 Labuapi Tahun Pelajaran 2015/2016. Jurnal Pendidikan Fisika dan Teknologi Volume II No 2 Hal. 80-85. Tersedia Pada : http://jurnalfkip.unram.ac.id/index.php/JPFT/article/view/293/0.

Kanca, I Nyoman. 2006. Metodologi Penelitian Keolahragaan. Singaraja: Jurusan IImu Keolahragaan, Fakultas Pendidikan IImu Keolahragaan, Universitas Pendidikan Ganesha.

Laa, Neli, Hendri Winata, Rini Intansari Meilani. 2017. Pengaruh Model Pembelajaran Kooperatif Tipe Student Teams Achievement Division terhadap Minat Belajar Siswa. Jurnal Pendidikan Manajemen Perkantoran Vol. 2 No. 2 Hal. 139-148. Tersedia Pada: http://ejournal.upi.edu/index.php/jpmanper/article/view/00000.

Nurkancana, Wayan dan Sunartana. 1992. Evaluasi Hasil Belajar. Surabaya: Usaha Nasional.

Peraturan Menteri Pendidikan Nasional Republik Indonesia Nomor 41 Tahun 2007 Tentang Standar Proses Untuk Satuan Pendidikan Dasar dan Menengah. 2007. Jakarta: Badan Standar Nasional Pendidikan.

Syarifuddin. 1997. Pendidikan Jasmani dan Kesehatan 3. Jakarta: PT Gramedia Widiasarana Indonesia.

Trianto. 2007. Model-Model Pembelajaran Inovatif Beronrientasi kontruktivistik. Jakarta: Prestasi Pustaka.

Muhamad,Hamid.2014. Panduan Penilaian Pendapaian Kompetensi Peserta Didik Sekolah Menengah Pertama.Jakarta:Kemendibud. 
Nikmah, Erlita Hidaya, Achmad Fatchan, Yuswanti Ariani Wirahayu. 2016. Model Pembelajaran Student Teams Achievement Divisions (STAD), Keaktifan dan Hasil Belajar Siswa. Jurnal Pendidikan Geografi Vol. 3 No. 3 Hal. 1-17. Tersedia Pada : http://journal.um.ac.id/index.php/pendidikan-geografi/index.

Kanca, I Nyoman. 2010. Metode Penelitian Pengajaran Pendidikan Jasmani dan Olahraga. Singaraja: Undiksha.

Koyan, I Wayan. Statistik Pendidikan. Teknik Analisis Data Kuantitatif. Universitas Pendidikan Ganesha Press.

Koyan, I Wayan. 2012. Evaluasi Program Pendidikan. Program Pasca Sarjana Universitas Pendidikan Ganesha.

Koyan, I Wayan. Statistik Terapan (Teknik Analisa Data Kuantitatif). Universitas Pendidikan Ganesha Press.

Merta,I Wayan, dkk. (2014). “Implementasi Model Pembelajaran Kooperatif Tipe Numbered Head Together NHT)”. Kerta Mandala, Volume 6, Edisi Khusus. (hlm. 159-177).

Roji. 2014. Buku Guru Pendidikan Jasmani Olahraga dan Kesehatan Kelas IX Semester Genap. Jakarta:Kemendikbud.

Roji. 2014. Buku Siswa Pendidikan Jasmani Olahraga dan Kesehatan Kelas IX Semester Genap. Jakarta:Kemendikbud.

Sriundy,Mahardika, I Made. 2010. Pengantar Evaluasi Pengajaran. Surabay:Unesa University Press.

Sugiyono. 2008. Metode Penelitian Pendidikan: Pendekatan Kuantitatif, Kualitatif dan R \& D. Bandung: alfabet.

Sugiyono, 2009. Statistika Untuk Penelitian. Bandung : Alfabeta.

Suharto. 2000. Tes Kesegaran Jasmani Indonesia Untuk Anak Umur 10-12 Tahun. Jakarta:Departemen Pendidikan Nasional.

Suhardi,Didik. 2014. Panduan Penguatan Proses Pembelajaran Sekolah Menengah Pertama. Jakarta:Kemendibud. 